\title{
Treated Wastewater Irrigation Promotes the Growth and Nodulation of Acacia Species
}

\author{
Nader Desouky Shetta ${ }^{1,2}$
}

\begin{abstract}
The scarcity of irrigation water is one of the vital factors limiting crop production in arid countries. The critical shortage of water necessitates the development of new water sources, and the use of wastewater is considered one of the best solutions for solving this water scarcity. An experiment was conducted to investigate the effect of primary treated wastewater irrigation on growth parameters, nodulation, macro and micronutrients for Acacia ampliceps (Maslin.) and Acacia origena (Hunde.) seedlings grown in the Dirab Valley, South of Riyadh City. The study included four irrigation treatments: municipal water plus Rhizobium inoculum (MWR), primary treated wastewater plus Rhizobium inoculum (PTWR), municipal water only (MW), and primary treated wastewater only (PTW). The results revealed that the PTWR and PTW treatments were effective for increasing the growth parameters and nodulation of the Acacia seedlings. The combination of primary treated wastewater and inoculation with Rhizobium significantly improved the growth parameters, nodulation, and nutrient content of the seedlings. Overall, the combination of treated wastewater and Rhizobium can be used as a potential source of nutrients and water for tree legume plantations in the arid areas of Saudi Arabia.
\end{abstract}

Keywords: Acacia species; Macro and micronutrients; Nodulation; Primary treated wastewater; Saudi Arabia.

\section{INTRODUCTION}

In many arid and semi-arid regions, water is becoming increasingly limiting resource, and therefore studies need to investigate untraditional ways to meet the increasing demand for water worldwide. Saudi Arabia is an arid country and scarcity of irrigation water is one of the major factors limiting crop production and higher crop yield (Al-Fredan, 2006). In Saudi Arabia, critical shortage of water necessitates the development of new water sources, and the use of wastewater is considered one of the best solutions. (Al-Othman, 2009; Al-Mefarrej, 2013).

The treated wastewater contains organic matter and nutrients that can improve soil and crop productivity. Currently, wastewater is being used for the restoration of degraded land and growth of commercial and environmental crops (Al-Fredan, 2006). After primary treatment, the wastewater becomes safe for irrigation of non-food crops, such as tree plantations, greenbelts, and forestlands (Hassan et al., 2006; Tabari and Salehi, 2009). Previous studies indicated that using sewage effluent for irrigation improved the soil properties and some growth parameters of forest trees, such as biomass potential, biomass allocations, specific gravity of the wood, fiber length, and volumetric shrinkage (Guang et al., 2010; Ali et al., 2011). Legume trees can absorb wastewater effluent and heavy metals through their root systems, thereby serving as effective biological filters and inhibiting contamination of groundwater sources. Nodulation and nitrogen fixation in the legumeRhizobium relationship is sensitive to water quality, therefore poor water quality can prevent legume growth and reduces crop yield. Both legumes and the nodule initiation process are more sensitive to osmotic stress than Rhizobium strains itself (Katerji et al., 2003; Goormachtig et al., 2004; El-Komy, 2005; Gehring et al., 2005; Junior et al., 2005 and Daudin and Sierra, 2008). Poor water quality can result in failure of the infection process and is considered one of the main reasons for unsuccessful symbiosis. In Saudi Arabia, treated municipal wastewater is one of the main sources used for agricultural purposes.

Acacia ampliceps (Maslin.) has been introduced to Saudi Arabia in 1980. It is regarded as a fast-growing dense shrub or small tree (3-9 $\mathrm{m}$ tall) with a spreading crown. It is adapted at the arid and semi-arid regions of Saudi Arabia. A. ampliceps is considered as a one of the most salt-tolerant species in Saudi Arabia, Acacia species are found on sand plains, flood plains, and along drainage lines (Doran and Turnbull, 1997; Marcar et al., 1999 and Aref et al., 2003). Acacia origena (Hunde.) is a medium sized tree $(6 \mathrm{~m}$ tall) that is native to Ethiopia, West Eritrea, and also across the Red Sea in Yemen and Saudi Arabia.

It is considered as an indigenous tree in southern Saudi Arabia as multipurpose trees, used for, fuel production and reforestation. However, in Saudi Arabia, there is a lack of information on the effect of wastewater irrigation on the growth parameters and nutrient uptake of woody legume trees inoculated with

${ }^{1}$ Forestry and Wood Technology Department, Faculty of Agriculture, Alexandria University, Alexandria 21545, Egypt

${ }^{2}$ Range and Forestry Applied Research Unit,

Plant Production Department, Food and Agriculture College,

King Saud University, Riyadh 11451, Saudi Arabia

Received October 12, 2016, Accepted November 23, 2016 
Rhizobium. Therefore, the aim of the current study was to evaluate the effect of primary treated wastewater irrigation on the growth characteristics of Acacia seedlings, inoculated with indigenous Rhizobium, under Riyadh region conditions.

\section{MATERIALS AND METHODS}

\section{Tree growth and soil characteristics}

This study was carried out in two successive growing seasonal 2014 and 2015 at the Experimental Station, Faculty of Food and Agricultural Sciences, King Saud University in the Dirab Valley, $60 \mathrm{~km}$ south of Riyadh City, Saudi Arabia. The physical and chemical characteristics of the soil used in the experiment are shown in Table (1).

The average temperature during the growing season ranged between $10{ }^{\circ} \mathrm{C}$ (winter) and $41^{\circ} \mathrm{C}$ (summer), with an annual rainfall of $50 \mathrm{~mm}$. The seeds of Acacia species $A$. ampliceps and A.origena were obtained from the King Saud University's Range and Forestry Applied Research Unit. Seeds were pretreated with hot water $\left(100{ }^{\circ} \mathrm{C}\right)$ for $15 \mathrm{~min}$, and kept in cool water for $24 \mathrm{~h}$, and then planted in plastic plates containing a mixture of vermiculate and sand (1:2 by volume). Germination started after 7 days, seedlings (two weeks age) were transplanted into plastic pots $(20 \mathrm{~cm}$ diameter $)$, and each was filled with $5 \mathrm{~kg}$ of soil. Fertilizer $\mathrm{Ca}\left(\mathrm{H}_{2} \mathrm{PO}_{4}\right)$, $2 \mathrm{CaSO}_{4}(0.33 \mathrm{~g} /$ plant $)$ was applied to the pots 30 days after planting.

\section{Seedling inoculation assay and experimental design}

The Rhizobium strain (DLR22) used for inoculation was isolated in 2014 from root nodules of Leucaena leucocephala (Lam.) seedlings which grown in a Range and Forestry Applied Research Unit Nursery. The isolates were harvested from healthy, unbroken, and pink root nodules collected from the field. Rootnodulating bacteria were isolated from the seedlings, following to the methods described by Vincent (1970). Seedlings were inoculated with the Rhizobium strain by applying $10 \mathrm{ml}$ of rhizobia (approximately $1 \times 10^{10}$ ) grown in yeast extract mannitol broth, with shaking (200 rpm). After 7 days of incubation period, the pots were organized in a randomized complete design with 5 replications (split plot in $\mathrm{CRD}, \mathrm{n}=40$ ). The environmental conditions were $24{ }^{\circ} \mathrm{C} / 17{ }^{\circ} \mathrm{C}$ (day/night temperatures), $13 \mathrm{~h} / 11 \mathrm{~h}$ (light/dark periods), 75\% relative humidity, and a photon flux density was 400 $500 \mu \mathrm{mol} \mathrm{m} \mathrm{m}^{-2}$. Four irrigation treatments were used: municipal water plus Rhizobium inoculum (MWR), primary treated wastewater plus Rhizobium inoculum (PTWR), municipal water only (MW), and primary treated wastewater only (PTW). All water treatments types had the same quantity $(650 \mathrm{ml})$ and irrigated during summer three times and twice every week in winter. The chemical characteristics of the irrigation water used in the study are shown in Table (2). Seedlings were harvested 120 days after planting, and the following measurements were recorded: seedling height and diameter; shoot, root, and total seedling dry matter; number of nodules per seedling; and dry weight of nodules. Seedlings were dried at $70{ }^{\circ} \mathrm{C}$, and the macro and micronutrients were determined. Total nitrogen content was determined using the Kjeldahl method (Kjeldahl, 1883). Potassium $\left(\mathrm{K}^{+}\right)$was determined using flame photometry (Corning 400, Sherwood Scientific Ltd, Cambridge, UK). Phosphorus (P) was determined using colorimetric determination. However, micronutrients; $\mathrm{Cu}, \mathrm{Fe}$, and $\mathrm{Mn}$ were measured using atomic absorption spectrophotometry (Perkin Elmer, PinAAcle ${ }^{\mathrm{TM}}$ 900F, Massachusetts, USA).

\section{Statistical analysis}

Data were statistically analysed using the analysis of variance procedure for a split plot system in complete randomized design (CRD) using SAS statistical software package program (version 9.10, 2001). The mean values were compared using the F-test, and L.S.D, considering a significance level of $\mathrm{p}<0.05$.

\section{RESULTS AND DISCUSSION}

\section{Growth and nodulation of Acacia species}

There were significant differences (p <0.05) between two Acacia species for seedling height and nodule dry weight, while seedling diameter, shoot and root dry weight were not significantly in the two seasons. Irrigation treatments significantly affected all the tested parameters, except nodule dry weight. Also, there were significant interaction effects between two Acacia species and the four irrigation treatments, except for root and dry weight of total seedling character, particularly in the second season (Table 3).

\section{Table 1. Physical and chemical characteristics of the soil used in the study}

\begin{tabular}{|c|c|c|c|c|c|c|c|c|c|c|c|c|c|}
\hline \multicolumn{3}{|c|}{$\begin{array}{l}\text { Particle size } \\
\text { distribution (\%) }\end{array}$} & \multirow{2}{*}{$\begin{array}{c}\text { Soil } \\
\text { texture }\end{array}$} & \multirow[t]{2}{*}{ pH } & \multirow{2}{*}{$\begin{array}{c}E C^{\dagger} \\
\left(\mathbf{d s} \mathbf{m}^{-1}\right)\end{array}$} & \multicolumn{3}{|c|}{$\begin{array}{c}\text { Soluble cations } \\
\left(\mathrm{mg} \mathrm{L}^{-1}\right)\end{array}$} & \multicolumn{2}{|c|}{$\begin{array}{l}\text { Soluble anions } \\
\left(\mathrm{mg} \mathrm{L}^{-1}\right)\end{array}$} & \multicolumn{3}{|c|}{$\begin{array}{c}\text { Available nutrients } \\
\left(\mathrm{mg} \mathrm{kg}^{-1}\right)\end{array}$} \\
\hline sand & silt & clay & & & & $\mathrm{Na}^{+}$ & $\mathbf{K}^{+}$ & $\mathrm{Ca}^{2+}$ & $\mathrm{SO}_{4}^{-2}$ & $\mathrm{CL}^{-}$ & $\mathbf{N}$ & $\mathbf{P}$ & $\mathbf{K}$ \\
\hline 78.7 & 14.0 & 7.3 & Sandy loam & 8.65 & 1.45 & 4.45 & 0.15 & 6.10 & 6.0 & 6.5 & 13.0 & 0.15 & 1.95 \\
\hline
\end{tabular}

${ }^{\dagger} \mathrm{EC}$ : electrical conductivity 
Table 2. Chemical characteristics of irrigation water types used in the study

\begin{tabular}{|c|c|c|c|}
\hline \multirow{2}{*}{ Properties } & \multicolumn{2}{|c|}{ Types of irrigationWater $^{\dagger}$} & \multirow{2}{*}{$\begin{array}{c}\text { Limits }^{\ddagger} \\
\text { FAO (1992) } \\
\end{array}$} \\
\hline & MW & PTW & \\
\hline $\mathrm{pH}$ & 7.75 & 8.25 & $6.5-8.4$ \\
\hline $\operatorname{Ec}\left(\mathrm{ds} \mathrm{m}^{-1}\right)$ & 0.15 & 1.90 & $3.0-7.0$ \\
\hline $\operatorname{TDS}\left(\mathrm{mg} \mathrm{L}^{-1}\right)$ & 92 & 1195 & $1920-44880$ \\
\hline \multicolumn{4}{|c|}{ Soluble cations $\left(\mathrm{mg} \mathrm{L}^{-1}\right)$} \\
\hline $\mathrm{Ca}^{2+}$ & $n d^{\S}$ & 153 & - \\
\hline $\mathrm{Mg}^{2+}$ & nd & 44.5 & - \\
\hline $\mathrm{K}^{+}$ & 0.80 & 9.36 & - \\
\hline $\mathrm{Na}^{+}$ & 16.0 & 219.5 & - \\
\hline \multicolumn{4}{|c|}{ Soluble anions $\left(\mathrm{mg} \mathrm{L}^{-1}\right)$} \\
\hline $\mathrm{CO}_{3}^{-2}$ & nd & 37.5 & - \\
\hline $\mathrm{HCO}_{3}^{-}$ & 31.0 & 145.0 & $91.5-518.5$ \\
\hline $\mathrm{Cl}^{-}$ & 27.0 & 313.0 & - \\
\hline $\mathrm{SO}_{4}^{-2}$ & 17.5 & 370 & - \\
\hline \multicolumn{4}{|c|}{ Total heavy metals $\left(\mathrm{mg} \mathrm{L}^{-1}\right)$} \\
\hline $\mathrm{Cd}$ & 0.004 & 0.009 & 0.01 \\
\hline $\mathrm{Ni}$ & 0.032 & 0.62 & 0.20 \\
\hline $\mathrm{Pb}$ & 0.013 & 0.209 & 5.0 \\
\hline $\mathrm{Zn}$ & 0.490 & 0.355 & 2.0 \\
\hline
\end{tabular}

${ }^{\top} \mathrm{MW}$ : municipal water, PTW: primary treated waste water; ${ }^{\dagger}$ Limits for agricultural reuse of wastewater (FAO, 1992); ${ }^{{ }^{\circledR} \text { not }}$ detected

The growth of the Acacia species was noticeably enhanced by using the PTWR treatment, and, to a lesser extent to PTW treatment. For both seasons, $A$. ampliceps had the highest values of seedling height and diameter followed by the A. origena seedlings (Table 4). The incensements in the seedling height were $69 \%$ and $13 \%$ for $A$. ampliceps and A. origena, respectively, while seedling diameter was $13 \%$ and $5.5 \%$ for $A$. ampliceps and A. origena, respectively, in the PTWR treatment than in the MW treatment. Several studies have also showed increasing in the growth parameters of trees and crops after irrigation with treated wastewater (Kiziloglu et al., 2008; Bedbabis et al., 2010; Akponikpèa, 2011; Pandey and Srivastava, 2012, and Selahvarzi and Hosseini, 2012). Moreover, Carvalho et al. (2012) found that the height and nodulation of Leucaena leucocephala and Mimosa caesalpiniaefolia significantly increased when treated with sewage effluent and inoculated with Rhizobium.

The seedling biomass of the two Acacia species is presented in Table (5). The shoot and root dry weight in PTWR and MWR were significantly differed with average of 2.7 and $1.31 \mathrm{~g}$, respectively, for A. ampliceps and 2.73 and $1.30 \mathrm{~g}$, respectively, for $A$. origena compared with the other treatments in the first season. In the second season, the shoot dry weight was increased significant only in PTWR with an average of $1.75 \mathrm{~g}$, while both the root and total plant dry weight did not show any significant effect. The same trends were noted in root and dry weight of total seedling in both

PTWR and MWR treatments, which gave high mean values. MWR treatment in $A$. origena gave the highest root and dry weight of total seedling values compared with $A$. ampliceps in the second season (Table 5). These results are in accordance with Shetta et al. (2009), who found that the total dry weights and the fresh and dry weights of stems and branches of Casuarina trees treated with liquid sludge where than higher for those dewatered sludge treated trees and control treatments. Also, Kaur et al., (2013) demonstrated the significant influence of rhizobia isolates on growth and biomass in Albizia lebbek seedlings.

Inoculation with appropriate Rhizobium isolates ideally compatible with the species and environment in terms of nitrogen fixation and assimilation enhanced the productivity of the forests and plantations. Most of leguminous plants are able to increase nitrogen fixation and remove heavy metals from the soil at the same time (Ike et al., 2007). The nodulation values for the Acacia species under the different irrigation treatments are presented in Table (6). Statistically, both MWR and PTWR are not different. For the two Acacia species, the MWR treatment induced had the highest mean value of nodulation and nodule dry weight/ seedling, followed by the PTWR treatment. In the first season, high mean nodules seedling ${ }^{-1}$ and nodule dry weight seedling ${ }^{-1}$ were noted for Acacia origena (14.2 nodules seedling ${ }^{-1}$ and $0.034 \mathrm{~g}$ nodule dry weight, respectively) than for Acacia ampliceps (10.4 nodules seedling ${ }^{-1}$ and $0.032 \mathrm{~g}$ nodule dry weight, respectively). 

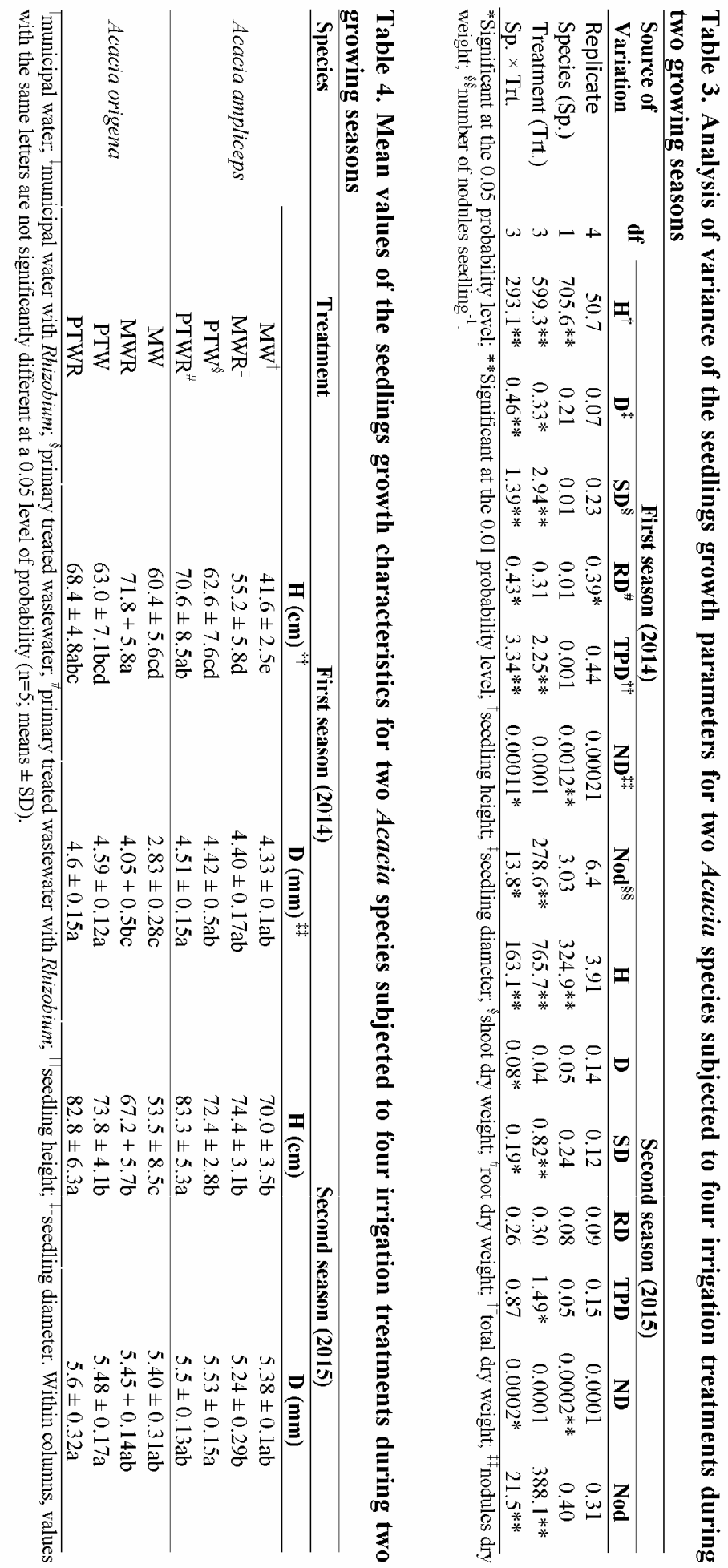

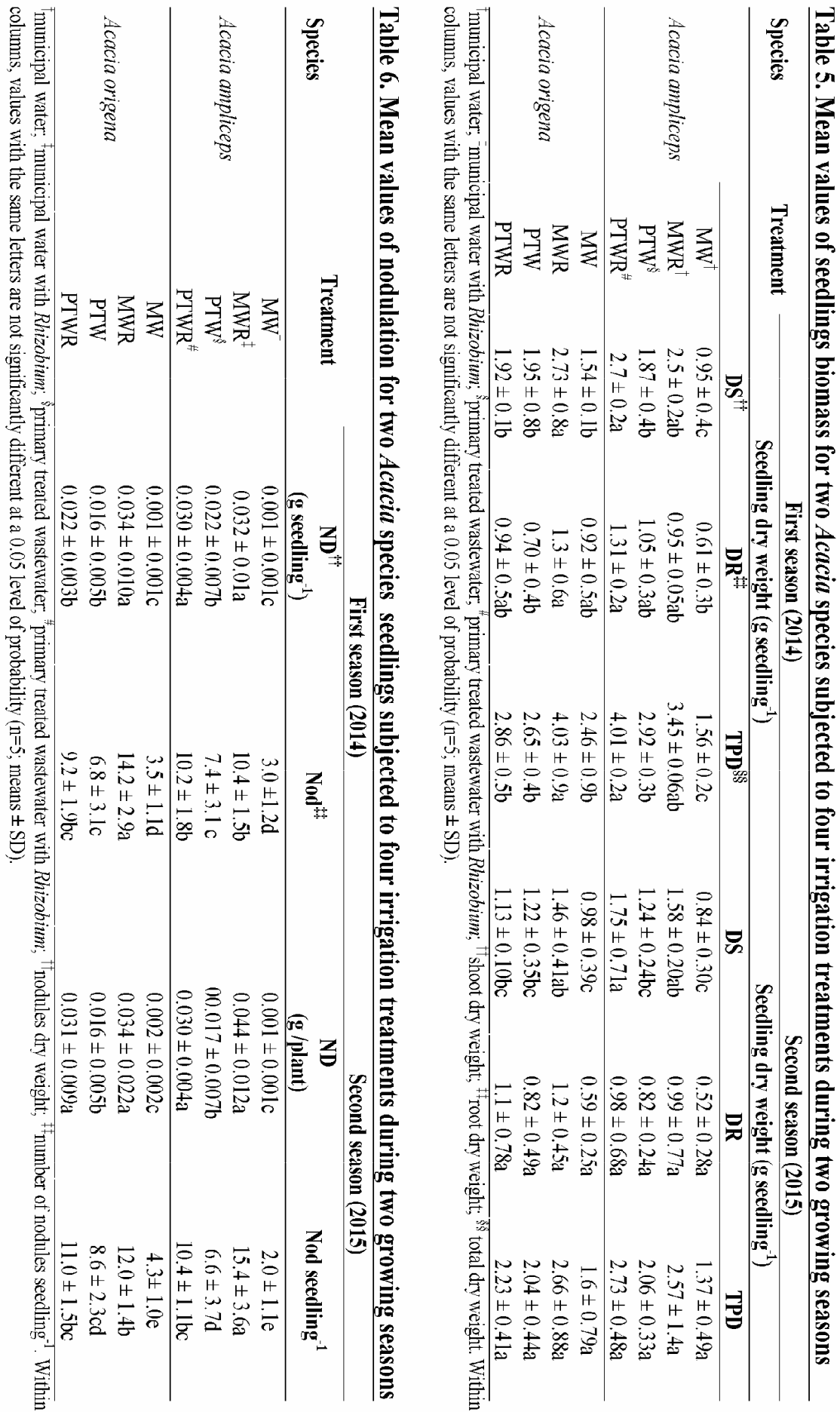
In the second season, higher mean nodules seedling ${ }^{-1}$ and nodule dry weight seedling ${ }^{-1}$ were noted for Acacia ampliceps (15.4 nodules seedling ${ }^{-1}$ and $0.044 \mathrm{~g}$ nodule dry weight, respectively) than for Acacia origena (Table 6).

In the Rhizobium-legume symbiotic relationship, the plant is the more sensitive to metal toxicity compared with bacteria. The nodulation and nitrogen fixation of legumes has been suggested as an indicator of soil pollution, based on the sensitivity of the host legumes and Rhizobium strains to heavy metals and industrial wastes. In polluted environments, nodules can help plants survive, because the bacteroids in nodules counter the metal stress (thiol inactivation), and this finding further supports the fact that symbiosis is mutually beneficial to legumes and rhizobia (Abd-Alla et al., 2012). In both Acacia species, the MWR and PTWR water treatments affected on nodulation, they significantly increasing the number and dry weight of nodules. Similar results have been reported in other studies (Stamford and Silva 2000; Al-Fredan, 2006; Carvalho et al., 2012). Abd-Alla et al. (2012, 1999) indicated that moderate application rates of sewage sludge increased the nodulation and nitrogen fixation in some legume crops. Overall, the nodulation results detected in this study are in agreement with the previous results of many studies (e.g., Michalak, 2006; Sharma et al., 2007; Selahvarzi and Hosseini, 2012 and AbdAlla et al., 2014).

\section{Macronutrients accumulation in Acacia species}

For both seasons, the concentration of N, P, and K in Acacia seedlings significantly $(\mathrm{p}<0.05)$ affected by species, irrigation application, and their interactions. Concentration of Nitrogen was insignificant in Acacia species (Table 7). In the first season, the mean value of $\mathrm{N}$ concentration was highest in the MW treatment (12.2mg seedling ${ }^{-1}$ ), while in the second season, the PTWR treatment resulted in the highest $\mathrm{N}$ concentration (12.01 mg seedling ${ }^{-1}$; Figure 1A). This result is in accordance with the finding of Abd-Alla et al. (1999), who found an increase in the $\mathrm{N}$ concentration in some legume plants. Also, phosphate $(\mathrm{P})$ concentration gave higher value in seedlings of Acacia ampliceps treated with the MWR treatment $\left(1.68 \mathrm{mg}\right.$ seedling ${ }^{-1}$; Figure 1B). Available $\mathrm{P}$ and $\mathrm{N}$ were highest in the PTWR and MWR treatments than that of the MW treatment, which is similar to the findings reported by Ali et al. (2011). The potassium $\left(\mathrm{K}^{+}\right)$concentration in the seedlings of Acacia origena showed an incensement at PTWR treatment with an average $127.6 \mathrm{mg}^{-1}$ seedling ${ }^{-1}$, in the first season and $206.8 \mathrm{mg}^{\text {seedling }}{ }^{-1}$, in the second season as compared with Acacia ampliceps under the same treatment. The maximum concentration of $\mathrm{K}^{+}$was 131.8 and $202.4 \mathrm{mg}$ seedling ${ }^{-1}$, respectively, in the two seasons (Figure 1C). Generally, the $\mathrm{K}^{+}$concentration in the Acacia species was higher in the second season than that of the first season. The present results were consistent with other studies, which indicated that the concentration of $\mathrm{N}, \mathrm{P}$, and $\mathrm{K}^{+}$increased in plants when treated with wastewater (El-Sayed, 2005; Singh and Bhati, 2005 and Selahvarzi and Hosseini 2012). These increases in the mineral concentration might be attributed to increases in the occupancy root zone. In addition, Falkiner and Smith (1997) found that irrigating Pinus and Eucalyptus spp. with sewage effluent increased the macronutrient concentrations in the forest soil.

\section{Micronutrients accumulation in Acacia specie}

In this study, trace elements concentration in the seedlings tissues was varied between species and tissues. During the two growing seasons, the $\mathrm{Cu}, \mathrm{Fe}$, and $\mathrm{Mn}$ concentrations were differed between Acacia species. In the first season, $\mathrm{Cu}, \mathrm{Fe}$, and $\mathrm{Mn}$ were highest in Acacia origena seedlings, while in the second season, Acacia ampliceps had the highest $\mathrm{Cu}, \mathrm{Fe}$, and $\mathrm{Mn}$ values (Figure 2). In the first season, $\mathrm{Cu}$ concentration was highest in Acacia origena seedlings treated with MWR, followed by seedlings treated with PTWR. In the second season, the highest $\mathrm{Cu}$ concentration was noted in the PTWR treatment $\left(6.4 \mu \mathrm{g}\right.$ seedling ${ }^{-1}$; Figure 2A). In the first and second seasons, Fe concentration was highest in Acacia origena seedlings treated with PTW (193.3 $\mu \mathrm{g}$ seedling ${ }^{-1}$ ) and PTWR (209.8 $\mu \mathrm{g}$ seedling ${ }^{-1}$ ), respectively (Figure $2 \mathrm{~B}$ ). For $\mathrm{Mn}$, the highest concentration in the first season was found for Acacia ampliceps seedlings treated with PTWR (182.1 $\mu \mathrm{g}$ seedling $^{-1}$ ) while, in the second season, Acacia origena had the highest concentration when treated with PTWR (181.2 $\mu \mathrm{g}$ seedling ${ }^{-1}$; Figure 2C). The wastewater may have contained large amounts of $\mathrm{Cu}$, Fe, and Mn, which improved nodulation of the Acacia species. These results were in agreement with those obtained by Sharma et al. (2007) and Selahvarzi and Hosseini (2012). In contrast, Ike et al. (2007) found decreased in concentrations of $\mathrm{Cu}, \mathrm{Fe}$ and $\mathrm{Zn}$ with longterm periods of soil irrigation. Accumulation of these metals in plant tissues can cause harmful effects on bacterial enzymes, and these metals cannot be chemically or biologically degraded (Abd-Alla el al., 2014). The results also demonstrated that inoculation Acacia species with Rhizobium combined with the application of the primary treated wastewater leads to significant improvements in seedlings growth parameters and macro and micro- nutrients contents. 


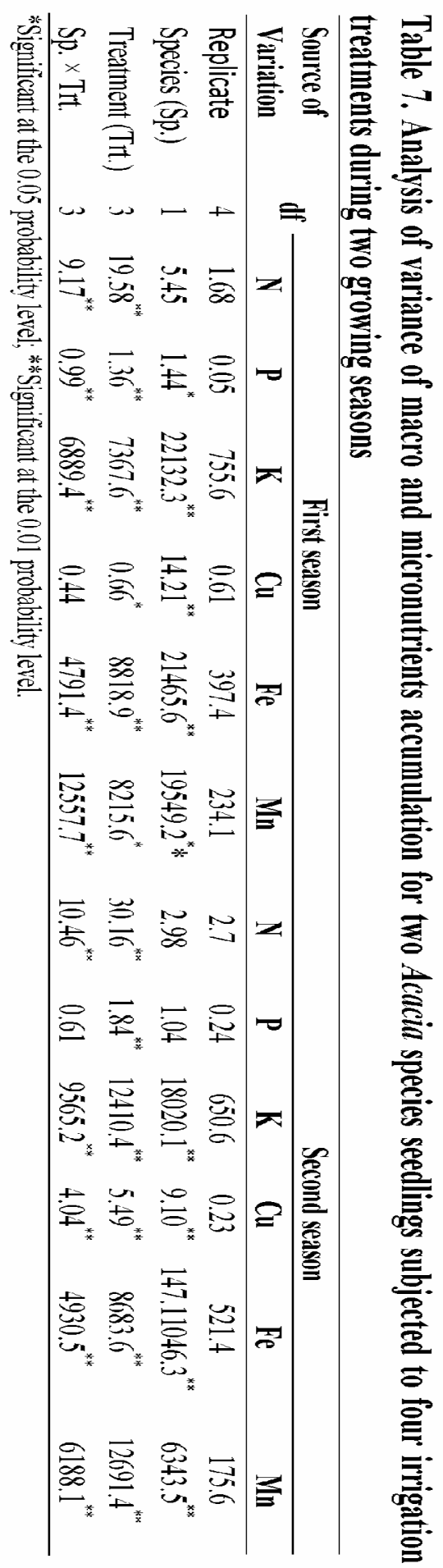



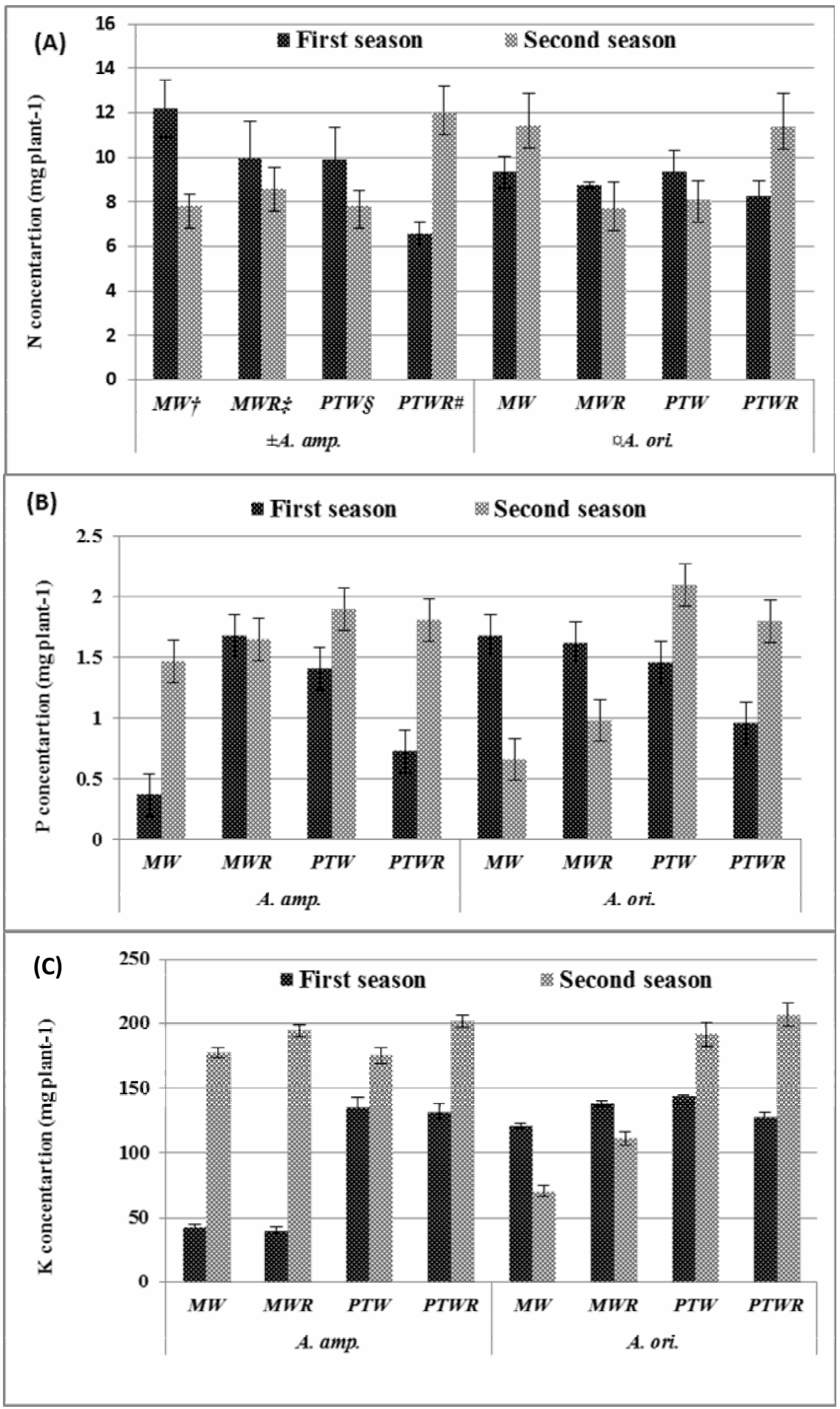

Figure 1(A, B and C). Effect of irrigation treatments on $\mathbf{N}(\mathrm{A}), \mathrm{P}(\mathrm{B})$, and $\mathrm{K}^{+}(\mathrm{C})$ concentration in Acacia species during two seasons. ${ }^{\dagger}$ municipal water; ${ }^{\ddagger}$ municipal water with Rhizobium; ${ }^{\S}$ primary treated wastewater; ${ }^{\#}$ primary treated wastewater with Rhizobium; ${ }^{ \pm}$Acacia ampliceps; ${ }^{\circ}$ Acacia origena $(\mathrm{n}=5$; means $\pm \mathrm{SD})$ 


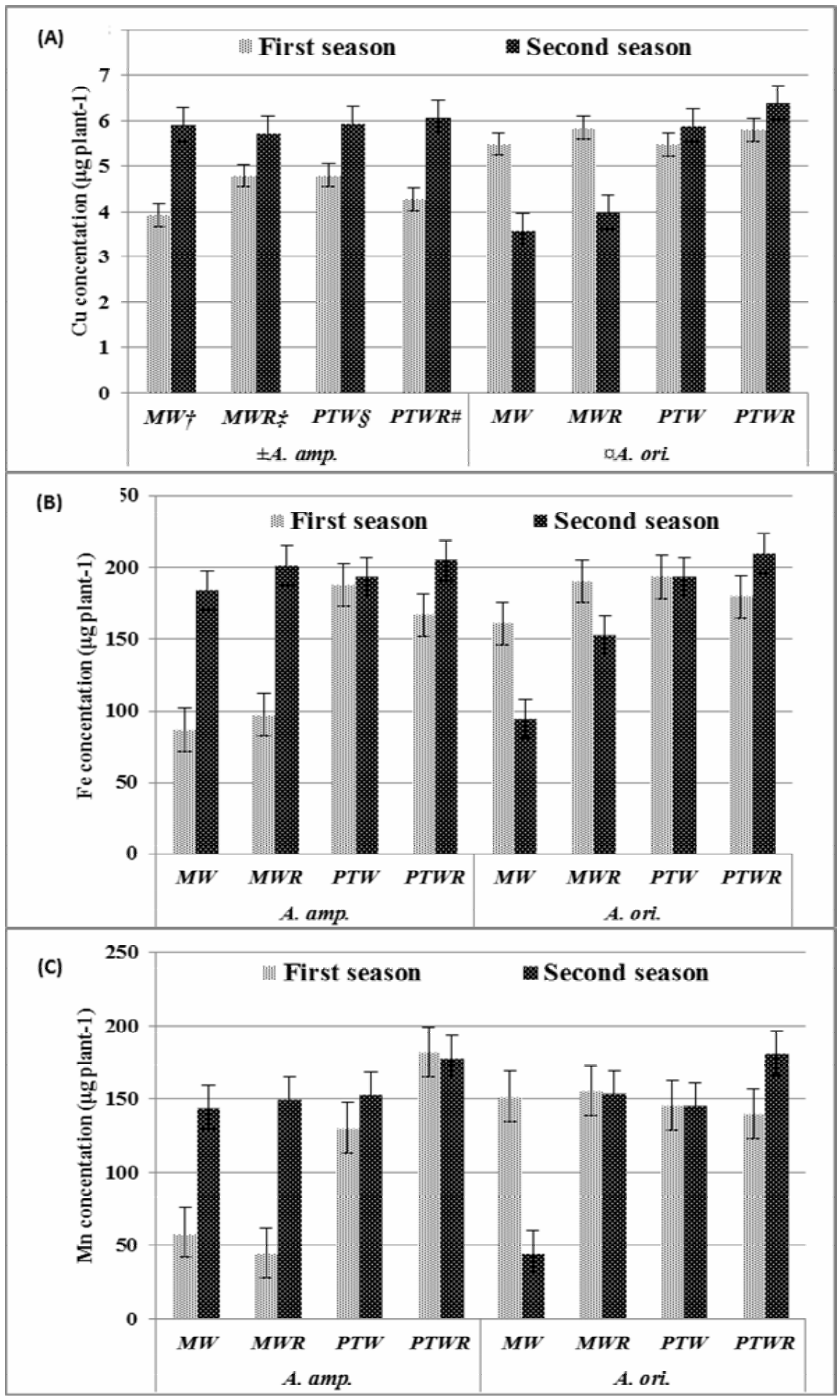

Figure 2 (A, B and C). Effect of irrigation treatments on $\mathrm{Cu}(\mathrm{A}), \mathrm{Fe}(\mathrm{B})$, and $\mathrm{Mn}$ (C) concentration in Acacia species during two seasons. ${ }^{\dagger}$ municipal water; ${ }^{\star}$ municipal water with Rhizobium; ${ }^{\S}$ primary treated wastewater; " primary treated wastewater with Rhizobium; ${ }^{ \pm}$Acacia ampliceps; ${ }^{\circ}$ Acacia origena $(\mathrm{n}=5$; means $\pm \mathrm{SD})$ 


\section{CONCLUSION}

Overall, primary treated wastewater was effective in increasing seedlings growth and can be used as an alternative resource in leguminous trees plantations. The results also demonstrated that, when combined with the application of the primary treated wastewater, inoculation with Rhizobium significantly improved the growth parameters, and macro and micronutrient content. In conclusion, this study showed that treated wastewater could be used as a potential source of nutrients and water for tree legumes. However, we suggest continued observations on the wastewater used in the agricultural purposes in order to ensure that the water is a suitable quality before it is readily used as an irrigation resource in arid or desert lands.

\section{ACKNOWLEDGMENTS}

The author thanks the King Saud University's College of Food and Agricultural Research Center and the Deanship of Scientific Research for supporting this work.

\section{REFERENCES}

Abd-Alla, H.M., F. Yan and S. Schubert. 1999. Effects of sewage sludge application on nodulation, nitrogen fixation and plant growth of faba bean, soybean and lupin. J. Appl. Bot. 73: 69-75.

Abd-Alla, M.H., M.K. Bagy, A.W.E. El-enany and S.R. Bashandy. 2014. Activation of Rhizobium tibeticum with flavonoids enhances nodulation, nitrogen fixation, and growth of fenugreek (Trigonella foenum-graecum L.) grown in cobalt-polluted soil. Environ. Contam. Toxicol. 66: 303-315.

Abd-Alla, M.H., F.M. Morsy, A.E. El-enany and T. Ohyama. 2012. Isolation and characterization of a heavy-metalresistant isolate of Rhizobium leguminosarum bv. viciae potentially applicable for biosorption of $\mathrm{Cd}^{+2}$ and $\mathrm{Co}^{+2}$. Int. Biodeterior. Biodegrad. 67: 48-55.

Akponikpèa, P.B.I., K. Wimab, H. Yacoubab and A. Mermoudc. 2011. Reuse of domestic wastewater treated in macrophyte ponds to irrigate tomato and eggplant in semiarid West-Africa: Benefits and risks. Agric. Water Manag. 98: 834-840.

Al-Mefarrej, H.A. 2013. Growth characteristics and some wood quality of Tamarix aphylla seedlings primary irrigated wastewater under drought stress. Asian J. Plant Sci. 12 (3): 109-118.

Al-Fredan, M.A. 2006. Effect of treated municipal wastewater and Rhizobia strains on growth and nodulation of faba bean (Vicia faba L. cv. Hassawi. Pak. J. Biol. Sci. 9(10): 1960-1964.

Ali, H.M., E.M. EL-Mahrouk, F.A. Hassan and M.A. ELTarawy. 2011. Usage of sewage effluent in irrigation of some woody tree seedlings. Part 3: Swietenia mahagoni (L.) Jacq. Saud. J. Biol. Sci. 18: 201-207.
Al-Othman, A. 2009. The impact of prolonged irrigation with treated domestic wastewater on drainage water using a simulation model. King Saud University, J. Agric. Sci., 21: $29-40$.

Aref, I.M. and L.I. El-Juhany. 2005. Response of Acacia seyal, Acacia negrii and Acacia asak trees to water stress under field conditions. J. King Saud Univ., 17: 75-83.

Bedbabis, S., B. Ben Rouina and M. Boukhris. 2010. The effect of waste water irrigation on the extra virgin olive oil quality from the Tunisian cultivar Chemlali. Sci. Hortic. 125: 556-561.

Carvalho, F.G., A. J. N. Silva, H. N. S.Melo and J. L. S. Melo. 2012. Effect of irrigation with sewage effluent and rhizobia inoculation on growth of tropical tree legumes in Northeast Brazil. Int. J. Agric. For. 2: 72-78.

Daudin, D. and J. Sierra. 2008. Spatial and temporal variation of below-ground $\mathrm{N}$ transfer from a leguminous tree to an associated grass in an agroforestry system. Agric. Ecosyst. Environ. 126: 275-280.

Doran, J.C. and J.W. Turnbull. 1997. Australian trees and shrubs; species for land rehabilitation and farm planting in the tropics. ACIAR Monograph no. 24. Australian Centre for International Agricultural Research, Canberra, pp. 384.

El-Komy, H.M.A. 2005. Coimmobilization of Azospirillium lipoferm and Bacillius megaterium for successful phosphorus and nitrogen nutrition of wheat plants. Plant Nutr. Food Technol. Biotechnol. 43: 19-27.

EL-Sayed, N.A.A. 2005. The impact of irrigation with treated wastewater effluent on soil bio-physicochemical properties and on growth and heavy metals content of some fodder trees grown on calcareous soil. Ph.D. thesis, Faculty of Agriculture, Tanta University. Egypt.

Falkiner, R.A. and C.J. Smith .1997. Changes in soil chemistry in effluent irrigated Pinus radiata and Eucalyptus grandis. Aust. J. Soil Res. 35: 131-147.

FAO, 1992. Wastewater treatment and use in agriculture FAO irrigation and drainage paper 47. Food and Agriculture Organization of the United Nations, Rome, pp: 169.

Gehring, C., P. L. G. Vlek, L. A. G Souza and M. Denich. 2005. Biological nitrogen fixation in secondary regrowth and mature rainforest of central Amazonia. Agric. Ecosyst. Environ. 111: 237-252.

Goormachtig, S., W. Capoen, and M. Holsters. 2004. Rhizobium infection lessons from the versatile nodulation behavior of water-tolerant legumes. Trends Plant Sci. 9: 518-522.

Guang-Cheng, S., L. Na, Z. Yu, Y.S. En and C.C. Ren. 2010. Growth, yield and water use efficiency of greenhousegrown hot pepper under time-space deficit irrigation. Sci. Hortic. 126: 172-179. 
Hassan, F.A., R. A. Nasser, S. S. Hegazy and N. A. A ElSayed. 2006. Biomass performance, specific gravity and fiber length of three tree species irrigated with sewage effluent and persistence and distribution of pollution indicator bacteria in soil. Proceedings of 1st International Conference on Strategy of Botanic Gardens, Volume 7, May 10-12, Giza, Egypt.

Ike, A., R. Sriprang, H. Ono, Y. Murooka and M. Yamashita. 2007. Bioremediation of cadmium contaminated soil using symbiosis between leguminous plant and recombinant rhizobia with the MTL4 and the PCS genes. Chemosphere., 66: 1670-1676.

Junior, M. A., A. S. T Lima., J. R. F. Arruda and D.L. Smith. 2005. Effect of root temperature on nodule development of bean, lentil and pea. Soil Bio. Biochem. 37: 235-239.

Katerji, N., J.W. Van Hoorn, A. Hamdy and M. Mastrorilli. 2003. Salinity effect on crop development and yield, analysis of salt tolerence according to several classification methods. Agric. Water Manag. 63: 37-66.

Kaur, A., S. P. Chaukiayl, A. Thakur and T. C. Pokhriyal. 2013. Effect of rhizobial inoculations on nitrogen metabolism of Albizialebbek seedlings. J . Forest Res. 24: 671-676.

Kiziloglu, F. M., M. Turan, U. Sahin, Y. Kuslu and A. Dursun. 2008. Effects of untreated and treated wastewater irrigation on some chemical properties of cauliflower (Brassica oleracea L. var. botrytis) and red cabbage (Brassica oleracea L. var. rubra) grown on calcareous soil in Turkey. Agric. Water Manag. 95: 716-724.

Kjeldahl, J. 1883. "Neue Methode zur Bestimmung des Stickstoffs in organischen Körpern" (New method for the determination of nitrogen in organic substances), Zeitschrift für analytische Chemie. 22 (1): 366-383.

Marcar, N. E., S. Ismael, A.K.M.A. Hossain and R. Ahmad.1999. Trees, shrubs and grasses for salt lands: an annotated bibliography. ACIAR Monograph no. 56.
Australian Centre for International Agricultural Research, Canberra, 316 pp.

Michalak, A. 2006. Phenolic compounds and their antioxidant activity in plants growing under heavy metal stress. Polish J. Environ. Stud., 15: 523-530

Pandey, A. and R. K. Srivastava. 2012. Wastewater treatment efficiency and biomass growth of short rotation bioenergy trees in modified overland flow land treatment system. Int. J. Environ. Sci. 3: 591-604.

SAS Institute Inc. 2001. SAS/STAT® 9.1 User's Guide. Cary, NC: SAS Institute Inc. USA.

Selahvarzi, B. and S. M. Hosseini. 2012. Survival, growth and mineral accumulation in ash Fraxinus excelsior $\mathrm{L}$. seedlings irrigated with water treatment effluent. Folia For. Pol., Ser. A. 54: 159-168.

Sharma, R. K., M. Agrawal and F. Marshall. 2007. Heavy metal contamination of soil and vegetables in suburban areas of Varanasi, India. Ecotoxicol. Environ. Saf. 66: 258-266.

Shetta, N.D., M.M.Abel-Aal and A.S. Mohareb. 2009. Effect of sewage sludge application on growth and tree productivity of Casuarina cunninghamiana. stand. Egypt. J. Appl. Sci. 24: 284-294.

Singh G. and M.Bhati. 2005. Growth of Dalbergia sissoo in desert regions of western India using municipal effluent and the subsequent changes in soil and plant chemistry. Bioresour Technol. 96: 1019-1028.

Stamford, N. P. and R. A. Silva. 2000. Efeito da calagem e inoculação de sabiá em solo da mata úmida e do semiárido de Pernambuco. Pesqui. Agropecu. Bras. 35: 10371045.

Tabari, M. and A. Salehi. 2009. Long-term impact of municipal sewage irrigation on treated soil and black locust trees in a suburban area of Iran. J. Environ. Sci. 21: 1438-1445.

Vincent, J.M. 1970. A Manual for the Practical Study of RootNodule Bacteria. Blackwell Scientific, Oxford. pp: 164. 


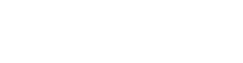

\section{الرى بميله الصرف المعالجة تعززمن نمو وتكون القد الجنربة لأشجار الكلسيا}

\section{نادر هسوق عبد الحميدشنا}

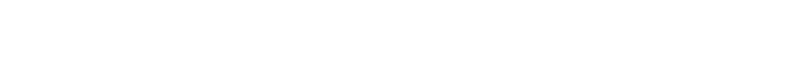

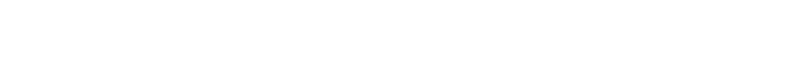

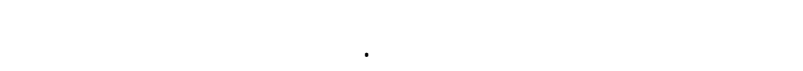

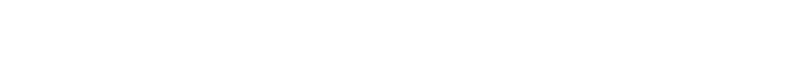

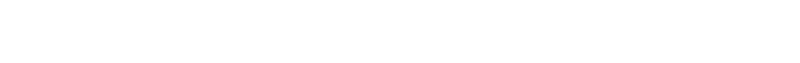
مستوى الأشجار من العناصر الكبرى والصغرى. ع ع للاوة

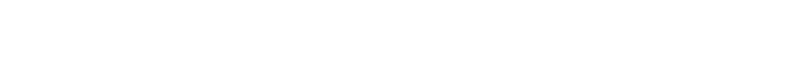

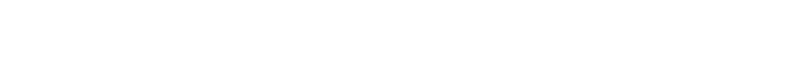

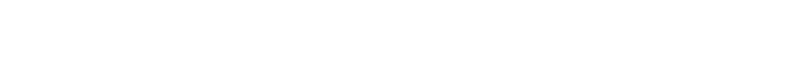
في المنطاق الجلفة من المملكة العربية للسعودية.

الكلمات الهشلكة: ميه الصرف المعالجة أوليًا، أشجار الأكلسيا، العناص ـر

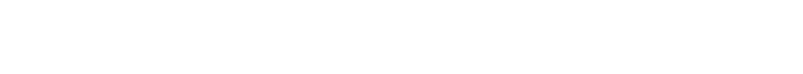
اللسعوية.
تعالى بلدان المنطلق الجافة من قص الميله وميله الرى المئر

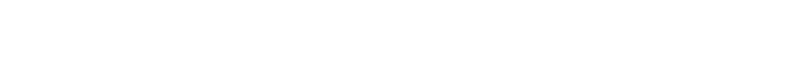

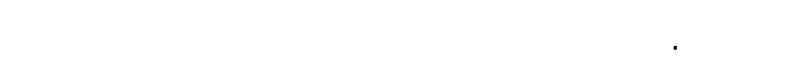

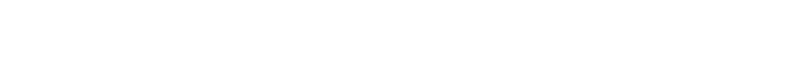

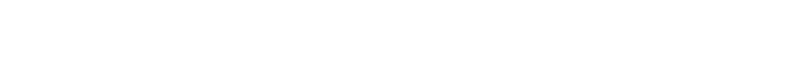

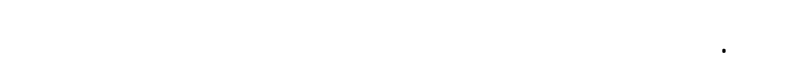

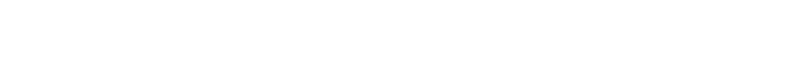

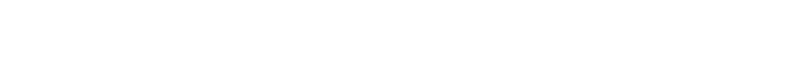
(Acacia ampliceps)

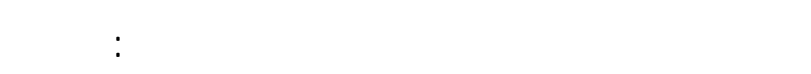

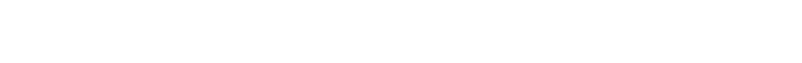

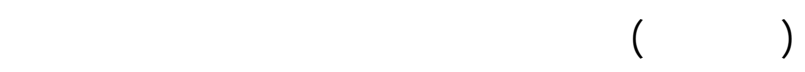

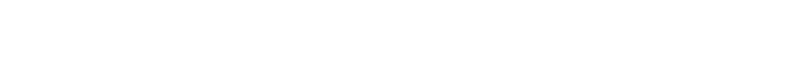

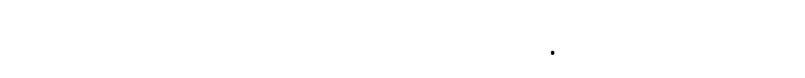

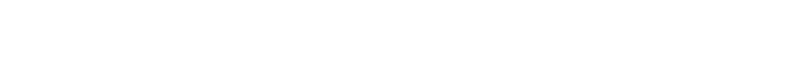

